\title{
Ortônimo, sinônimo, homônimo: retórica do anônimo
}

\author{
JOÃO ADOLFO HANSEN \\ Departamento de Letras Clássicas e Vernáculas \\ Faculdade de Filosofia, Letras e Ciências Humanas \\ Universidade de São Paulo
}

\begin{abstract}
RESUMO: Nos Diálogos platônicos, as questões retóricas incluemse como mimontologia ou dramatização de tipos e gêneses ideais. A discussão da linguagem, no Crátilo, e a da dialética, no Sofista, diagramam uma "semântica" original e sua sintaxe "or-tótica", prescritas como base não-mimética da mímesis como alétheia oposta às práticas sofistas do discurso.
\end{abstract}

PALAVRAS-CHAVE: Mímesis, diégesis, dialética, ônoma, rhéma, ontologia,eídos, sofista, verossimilhança.

"Nome nem condição valem. Os caetés comeram o bispo Sardinha, peixe, mas o navegador Cook, cozinheiro, também foi comido pelos polinésios. Ninguém está a salvo." (Guimarāes Rosa, 1967, p. 146)

O mal da paródia é que ela faz falar o outro, que nega: representa e, portanto, também nāo está a salvo. Nem este texto, que se atreve a atacar a questão retórica em Platão pensando-a no como questão técnica, como passou a ser entendida a partir da sistematização romana de Aristóteles e, menos ainda, depois que foi arruinada no século XVIII, como a retórica restrita à elocução subjetivada de românticos e modernos. $O$ que aqui se deseja é, antes de tudo, o homônimo: humor e simulacro do não-filosofema lendo o Filósofo como a ficção, que tạmbém é. Diz-se, com isso, que não se lêem os Diálogos para neles se buscar a fundamentação de um fundamento passível de ser traduzido em termos filosóficos, lingüísticos e outros, como ùma hermenêutica; embora também o faça, este texto se apropria deles preferencialmente segundo outra tática. Considera política a questão retórica encenada neles; por isso a propõe como determinada essencialmente pela operação de fundamentação ontológica da verdade. E duplamente: nos Diálogos, a enunciação platônica é uma pragmática que constitui uma "semântica" original, em que pesem todos os anacronismos, inevitáveis.

Em outras palavras, nos Diálogos a questão retórica inclui-se numa mimontologia $^{1}$, ou uma teatralização de gêneses e tipos ideais - entre eles, a da origem do discurso, teorizado como forma não-mimética da mímesis. E certo que nomeá-la 
assim, ou deslocá-la, ou criticá-la, ou parodiá-la, não exime este texto de também ser incluído e devorado no ato mesmo da nomeação. Logo, a operação de leitura acrescenta-se aqui de um suplemento de incerteza, dada a complexidade radical da economia política do discurso nos Diálogos, evitando-se toda boa intenção de totalização do gênero "A Retórica em Platāo", coisa por definição equivocadamente mítica a rebater-se no Anônimo impredicável do título deste. Sua operação consistira, basicamente, em desmontar-lhe o dispositivo aqui e ali, entendendo-o como conjunto de táticas erísticas que, sendo produtivas, pretendem-se porta-voz de um Original anterior a toda prática.

O desmonte se faz principalmente a partir do Crátilo e do Sofista, em que a discussão da linguagem, no primeiro, e da dialética, no segundo, formula o diagrama de uma "semântica" original e de sua sintaxe reta, postuladas como critérios do verdadeiro e do falso e, logo, como fundamento poiético do que é um verossímil retórico, que desloca o kairós da antiga enunciaçāo ritual, substituindo-o pela verificação teórica da verdade dos enunciados. Outros textos são convidados para o ágape: Protágoras, Gorgias, República, Fedro, Fédon, Teeteto, Eutidemo, Filebo - e o intertexto, que é impossível referir. Em sua leitura, a ánoia sofística, segundo a expropriação efetuada de discursos cujas regras diferem das de Platão, será aqui oposta à theoría ${ }^{2}$ também sofisticadamente mimetizada pela personagem Sócrates, outro de Outro. A expropriação atinge o próprio termo "sofista" e, de mero sabedor, de mero téćcnico ou lógico de discursos paradoxais, será capturado com o discurso da contradição e remetido para a zona dos falsos pretendentes à palavra real. A leitura requer um atalho, porém, kairós, que leva à técnica oratória de Protágoras. Mais adiante, à de Górgias.

Segundo Sexto Empírico, o sofista Protágoras de Abdera afirmava que "toda phantasía é verdadeira" (Sexto Empírico, 1954, 80 A, 15, p. 258). A citação de Sexto ecoa desde o Eutidemo platônico, onde se lê ter sido Protágoras o primeiro a empregar na discussão erística o argumento de Antístenes, o Cínico, de que não há contradição ( Platão, 1949). E, por exemplo, o que escreve Diógenes Laércio (Diógenes Laércio, 1954, 80 A, 1, p.253). A consequiência, em chave já platônica, é a negação do erro, de tal modo que, como afirma Sêneca, "pode defender-se com igualdade (ex aequo) o pró e o contra de qualquer questão, inclusive da questão de se saber se, em qualquer questão, o pró e o contra são defensáveis" (Sêneca, 1954, 80 A, 20, p. 260) ${ }^{3}$. Conta-se também que Protágoras, autor de uma taxinomia da frase grega, um dia censurou o rapsodo que recitava a fórmula " a ira canta, $\delta$ deusa..." com entoação imperativa: medida é optativo, uma vez que o Poeta dirigira súplica à deusa, não ordem, diria o sofista, para quem desmedida também teria sido a flexão feminina de mênis, pois "a ira" é do gênero masculino (Aristóteles, 1946, 56b) ${ }^{4}$.

Como sempre, neste texto, os exempla e seu simulacro de erudição estāo presentes para evidenciar algo in absentia, e que neles se pode reconhecer com os bons préstimos classificatórios de Aristóteles: Protágoras pensaria as modalidades da enunciação como atos singulares de (no) discurso, variáveis segundo os variáveis éthe ou caracteres dos locutores. Relacionando pensamento e discurso, os exemplos também apontam para uma pragmática: conforme Protágoras, a enunciação não expressa nem designa substâncias prefixadas numa classe; categoria ou combinatória, mas é singular, dando-se como evento ou jogo discursivo sempre móvel de asserções determinadas pelo kairós, bom momento, oportunidade. 0 exemplo da censura ao rapsodo parece confirmá-lo, pois Protágoras não o critica 
em nome de uma norma prefixada e seu conseqüente desvio como erro ou inadequação, mas em nome da medida da oportunidade. $O$ relativismo lingüístico, medida oportuna do heraclitismo de Protágoras (Platão, 1931, 440 a/d; 1950, 152 e, 166a, 167 d; 1952, 90 c; Ramnoux, 1968, p. 225), escorre dos discursos, espraia-se como agonística em qualquer causa em que esteja em jogo um discurso; é ele, também, que permite imaginar-se a liberdade da argumentação dos discípulos em suas liçōes, treinados para afirmar a cada vez múltiplas disposições platonicamente contrárias e contraditórias, como conta a tradição.E o mesmo relativismo, como instrumentação passível de ser apropriada por jovens aristocratas ambiciosos do poder político, que incita Platão à fixação do discurso e, para tal, à caça de lobos lógicos para domesticá-los como cães poéticos, escorraçados de sua gráfica.

Como variabilidade do ato de conhecer, variação do conhecimento na ordem do tempo, variância do discurso e igual valor de afirmaçōes contrárias para homens diversos ou para o mesmo homem em diferentes momentos, o discurso da agonística de Protágoras articula-se numa técnica retórica (Saita, 1938), entre outras, marcando-a com o relativismo da argumentação e com a habilidade de compô-la em asserções cujo fim é convencer. Num discurso também agonístico, Isócrates descreve pejorativamente sua ação: "Os erísticos chegaram a tal audácia que procuram persuadir os jovens de que, freqüentando-os, conhecerão o que devem fazer e graças a esta ciência se tornarão felizes" (Isócrates, 1956, I).

Nessa técnica, a retórica apresenta-se com duas faces distintas e complementares, dialética e elocução. Os jovens áristoi interessados na sua apropriação política na agorá deveriam, nas liçōes, apropriar-se dos procedimentos aptos a conferir-lhes, além da técnica do maravilhamento efetuado pela força dos meios discursivos, a agilidade para mover-se entre aporias de divisões e subdivisões de palavras. Assim, por exemplo, com a noção de orthoépeia, que Quintiliano traduz por recta locutio, pensando-a em termos do prépon aristotélico (Quintiliano, s/d, IV, X/XI), Protágoras pressupunha um processo analítico que, decompondo e classificando a causa em questão em elementos, determinava-lhes a argumentação própria a cada vez pois, segundo ele, propriedade de linguagem é propriedade de pensamento. Não se leia "propriedade", porém, nos espelhos da similitude, da analogia, da figura ou da representaçāo, pois o critério de orthoépeia aplica-se a cada vez a casos singulares da enunciação, nāo sendo predeterminado como adequação a nenhum universal do qual fosse, por exemplo, um diagrama ou uma repetição modelar e proporcional. Passando ao lado da semelhança da mímesis, cada situação discursiva admite a mesma e outra enunciação ao mesmo tempo, não como argumentação "melhor" ou "pior", ou "verossímil" ou "inverossímil", graus da semelhança, mas como argumentação mais forte ou mais fraca, quando não duas contrárias ou duas contraditórias simultaneamente. Desta maneira, medida é o pragmático e oportuno. Por isso, também, quando é lida através das prescrições generalizantes e genéricas da retórica aristotélica, a retórica de Protágoras não supera a imediatez da empiria e da força pragmática - o que significa que é outra, no que seja inferior, "sofística" (no sentido que Platāo constitui) ou, ainda, menos probante. Ela prova sempre, mas de maneira aristotelicamente paradoxal, pois não pressupõe o universal ou a identidade: de modo platonicamente mimético, ela não admite a semelhança, afirmando que o não-ser não é.

Nas Refutações Sofisticas, Aristóteles escreve que uma das finalidades da agonística sofista é, na discussão erística, levar o adversário a uma asserção paradoxal, paralógica, em que a decisāo pelo que é conforme a natureza ou conforme 
a convenção (to katd phýsin kai katd nómon), eixo das discussōes, implica sempre o mesmo impasse (Aristóteles, 1939, 4. 165 b, 166b) ${ }^{5}$. Para dominar o adversário, o sofista manipula operaçōes dialéticas enredantes, como a que identifica o dictum, expresso da enunciação - digo que - com o modus, enunciado do estado de fato - tal ocorre; ou a que faz o pressuposto regredir infinitamente; ou a que substitui sinônimos por homônimos etc. Tais técnicas evidenciam sempre que o discurso não é nem de participação numa Forma nem de adequação a opináveis, éndoxa, uma vez que o objeto da enunciação é efetuado de modo indeterminado, um e outro simultaneamente, flutuando com a oportunidade. Tudo $\varepsilon$ ato, enfim, na agonística generalizada que dissolve identidades no humor, pois "é próprio do sofista inventar novas razões", como acusa o mau-humor tradicionalista do cômico Aristófanes.

No diálogo platônico homônimo, o velho sofista Protágoras, figurado como personagem digna de veneração, no obstante a paródia agudíssima da situação dos ouvintes basbaques, deixa entrever o éthos empirista de sua prática quando pergunta à personagem Sócrates se deseja que discorra através de mito, de interpretação de poema ou de discurso explicativo, longo e corrido( Platão, 1955, 320 c). Em qualquer que se escolha, evidencia-se que a argumentação vai sendo quantificada pela grande extensão do discurso e que o ouvinte, torpedeado pelo acúmulo, não a acompanha totalmente, perdendo-se em algum meandro da fala, deixando-se falar pela força demonstrativa da duração. Assim, independentemente do que hoje se diria a "forma do conteúdo" ou a informação veiculada, o discurso de Protágoras vence, devido às táticas de suas formas de expressão. Sócrates, contudo, leva-o à técnica dialógica, que é a sua, na qual as questōes e as respostas, pela imediatez da enunciação, analisam a informação pontualmente, além de evidenciarem sempre a pessoa própria dos interlocutores, impedindo que se "disfarcem" nos efeitos. Como é sabido, Protágoras "perde" a discussão ou, pelo menos, muda de opinião. O que de modo algum é casual, no diálogo, uma vez que a técnica dialógica, que Sócrates exercita e domina como técnica dialética, é também o diagrama da natureza das duas concepções de retórica encenadas, como uma questão que se dissemina pelos outros. A sintaxe dialógica, ordenada como rede de palavras cujas malhas vão-se estreitando mais e mais pela divisão e subdivisão encadeadas de idéias e pela contínua retomada de elementos subdivididos, numa espécie de tecer de trama e lançadeira, ou de "pescador e linha", como Platão obliquamente a refere no Sofista, é um ícone mesmo do modo como Platão pensa a retórica, quando a subordina à sua teoria da enunciação reta, como orthótes.

Nos Diálogos, afirma-se que é na enunciação - léxis - que se investiga a origem do falso e, portanto, do verdadeiro. Ora, os dissol lógoi ou argumentos duplos de que Protágoras lança mão permitem-lhe afirmar que tudo é verdadeiro. Para contraditá-lo, Platão utiliza argumentação semelhante à que emprega, por exemplo, quando trata da "mentira mítica". Esta é dada como produto da irresponsabilidade poética, como uma espécie de perversão da prática poiética. É que os poetas são irresponsáveis porque dão aparência de autonomia aos discursos. $O$ crivo da análise "poética" platônica é, por isso, o da dissimulação ou não-dissimulação do autor da enunciação no enunciado que produz 6 . Assim, o poeta pode certamente falar em seu próprio nome - sem passar por outro e sem recorrer à citação de palavras de outros - tendo-se a haplè diégesis, ou "narrativa simples". Se o poeta se dissimula com aquele que figura no discurso, contudo, e, como um apócrifo, vai-se falando outro, dando-se a ver como o que não é, expondo-se duplo 
ou múltiplo e des(a)propriando-se, tem-se mímesis. A mímesis efetua-se como des(a)propriação da enunciação e na enunciação: ao mesmo tempo que oculta o próprio, desloca o lugar da fala própria, remetida ao verdadeiro, o lugar político próprio do filósofo. É a mimesis que instaura o poder fascinante dos mitos - por exemplo, as belas mentiras de Homero ou Hesíodo - e da linguagem em geral. $\mathrm{Na}$ enunciação, portanto, a dramatização do locutor é virtualidade sempre à espreita com os espelhos deformantes da homonímia. Falar é muito perigoso, pois quem o faz se arrisca a incidir num mimetismo generalizado, desinstalando-se na enunciação e - mal político - levando os ouvintes a crer no duplo e no múltiplo, $d \delta x a$. Platonicamente pensado, o discurso enquanto léxis ou enunciação deve pressupor uma poética normativa. Só o discurso diegético, ou simples, assumido pelo autor capaz de simplicidade, de nāo-duplicidade ou de nāo-multiplicidade é ortônimo, reto: lei do Próprio.

A mesma armadilha montada para poetas também é armada na caça ao estranho "animal", como Platão chama o sofista. Disparada, como no caso de Protágoras, a multiplicidade nômade dos sofistas será engaiolada e convertida num gênero de animal doméstico ou domesticável, o Sofista, com suas decorrentes linhagens mais ou menos impróprias, inverossímeis, superficiais, erradas e falsas. Assim, por exemplo, no Livro $\mathrm{X}$ da República, Sócrates diz - como personagem da escrita platônica - que todas as coisas do gênero mimético "são feitas para contaminar (lóbe) o julgamento (diánoia) dos que as escutam, - todos aos que falta o remédio/veneno (phámakon) que é precisamente o de conhecer (eidénai) o conjunto do ente tal que ele se presenta (auto oîa tynkhánei ónta)" (Platão, 1948, X, 595 b).

A fala é estranha, pois é fala da personagem Sócrates, figurada na escrita como porta-voz de Platão, contra os males da mimesis. 'A contradição, contudo, atenua-se e, como logo se verá, diégesis é mímesis: a diferença é de grau na participação na Forma, podendo-se ler os Diálogos, por isso, como uma teatralizaço anti-teatral $^{7}$ que visa, entre outros fins, a capturar, constituir unitariamente, e anular a ação do operador de prodígios, thaumastós anér, o sofista, de que são exemplos Protágoras, Górgias, Pródicos, Hípias, Trasímaco ${ }^{8}$.

E a determinação platônica do ser como eîdos/idéa, presença no aspecto, Anwesen im Aussehen - tradução de Heidegger -, pressupondo-se a interpretação da verdade como alétheia (não-esquecimento, desvelamento ou Unverstelltheit) (Heidegger, 1971, I, p.166-167; Beaufret, 1973) que leva à imposição/prescrição de uma técnica discursiva considerada reta, isto é, segura das leis de combinação ontológica no discurso, que o fazem apophantikós, no sentido definido, por exemplo, por Aristóteles: "Todo lógos é semantikós (...) mas nem todo lógos é apophantikós: só o é o lógos ao qual cabe dizer o verdadeiro ou o falso. Isso não é próprio de todos os lógoi" (Aristóteles, 1936, 4, 17 a). O sofista é efetuado por ela como um politécnico, que fala embaralhando os aspectos e que, misturando as presenças, produz indeterminação em simulacros, phántasma. A técnica platônica também o classifica, por isso, como deinós, perturbador da oposição ontológica fundamental que a valida, a oposição de presente/no-presente. Definindo-o como ser mimético por excelência, ela demonstra que o sofista finge ignorar a mimesis, acompanhando a demonstração do indecidível que ronda sua prática como um fundo emergente e informe que tolda e ameaça a presença plena. Dois perigos máximos da sua ação mimética são a efeminação e a loucura, males políticos, como deixa explícito o início do Livro III da República. Assim, quando o acua com sua rede de palavras, Platão visa a constituir-lhe os prodígios como jogos de espelhos, algo estranhamente 
morto, misturado, pois deinón é esse "nem morto, nem vivo", indecidibilidade que oblitera a presença e prolifera nas "ficçōes" da agonística sofista e da irresponsabilidade poética. Como, por exemplo, nos discursos de Górgias.

No Fedro, quando Sócrates critica o discurso de Lísias, tomado como exemplo da "velha" retórica siciliana, opõe-se a ela a técnica ática, fundamentada por Górgias e seguida por Isócrates e pelo rival deste, Alcidamas (Platão, 1944). Como esclarece Diès, o retor da escola de Lísias não procurava manter contato "sentimental" com seu ouvinte( Diès, 1927, p. 102-104) ${ }^{9}$ - quando queria persuadir, fazia-o por meio de análises "psicológicas" (as aspas remetem ao psicologismo de Diès) e de raciocínios dialéticos, cuja finalidade seria, em princípio, a de uma convicção racional. A palavra de ordem do discurso era, por isso, eikós, verossimilhança (Diès, 1927, p.102-104). O orador êmulo de Górgias - como pode ficar patente no seu Elogio de Helena - não se importaria, por isso, em extrair uma conclusão das matérias da causa, mas, pela sua manipulação hábil, tentava produzir um afeto, como uma "impressão" (Diès, 1927, p.102-104). Esta dependeria sempre da disposição momentânea do ouvinte e, óbvio, de afetos recebidos anteriormente. Segundo Górgias, o discurso efetua, assim, nāo uma análise das matérias mas uma transformação do "valor" delas para produzir-se um efeito exigido pelo ouvinte e circunstâncias. Por isso, os seus alunos eram treinados a ocupar-se não tanto da matéria, mas da maneira do discurso. Embora favorável às ciências especiais, posicionando-se contra Protágoras, como se pode ler no Elogio de Helena, o lema de Górgias também era oportunidade, bom momento ou ponto de vista, o kairós.

Diógenes Laércio atribui a Górgias uma tékhne que seria menos obra de teoria que um conjunto de receitas práticas, com esquemas ou exercícios para serem decorados, como exemplifica o paígnion do Elogio de Helena ou da Apologia de Palamedes, discursos "inesperados" que contrariam a opinião estabelecida sobre as personagens e que, não obstante, convencem. No diálogo platônico que leva seu nome, Górgias define a retórica como produtora de persuasão (Platão, 1949,452) de modo que coisas, atos e eventos são eventos, atos e coisas não por si, mas pela força, dýnamis, neles infundida pelo discurso. A posição de Górgias, cética, coincide talvez com a de seu discurso do Náo-Ser ${ }^{10}$ : a palavra "constrange a mente que persuadiu tanto a crer nos ditos quanto a consentir nos fatos" (Górgias, 1954, p.271-307, II). Isto porque o discurso é dynástes mégas, avançando com a violência do conquistador e com os passes de mágica do prestidigitador. Por isso, em sua caçada, Platão associa discursos como os de Górgias ao mal político que pode assolar a pólis na pessoa do tirano: o lógos sofista também é tyrannikós. Em Górgias, ainda, a negação do ser e a da relação entre o conhecedor e o ser implicariam a impossibilidade mesma da comunicação autêntica, pois a ausência de identidade e de relação fixa entre as palavras e as coisas impediria a mesma comunicação do ser das coisas (Rey, 1973, I). Disso também se segue, pela analogia dos meios e fins da persuasão e da cura dos corpos, uma comparação continuada da retórica com a medicina, como se lê no Górgias e no Protágoras, comparação que Platão, obviamente, renega, degradando-a para a dimensāo de uma cosmética ou culinária. Entre Protágoras e Górgias, portanto, apesar do heraclitismo de um e do eleatismo paradoxal de outro, há um ponto em comum. Por exemplo, no Teeteto, Protágoras deduz, pelo seu relativismo, a transformação dos valores na qual se resume, segundo ele, toda a tékhne humana: Educaçāo e Agricultura, Retórica e Medicina (Platão, 1950, 166a, 168 e). Por essa transformação, o lógos é assimilado a um organismo, zóon, do que decorre não só a predileção por clichês de argumentação aprendidos 
de cor e aplicáveis a qualquer situação como elementos combináveis de um "corpo", como também um ensino baseado nos talentos de cada aluno, como desenvolvimento de uma disposição inata (Diès, 1927,p. 101-104), e, não se perca o trocadilho, como pagamento, prova de que o século IV a.C. foi a idade de ouro de professores talentosos.

À persuasão efetuada pela crença sem o saber, que é a do kairós sofista segundo sua ótica, Platão opõe a persuasão doada pela verdade com o saber, e que é a sua. Com ele se sistematiza o mito ocidental de qué poder e saber são irreconciliáveis, pois o homem do poder é o homem da ignorância, distinguindo-se do homem do saber e da sua ascética contemplação do Anônimo. Sobre o tema, reciclando Nietzsche, Foucault tem páginas muito agudas ${ }^{11}$.

Na luta platônica contra as retóricas sofistas, a mimesis é teorizada, pois, como desapropriação de um saber verdadeiro. Assim, quando Platão critica a produtividade politécnica, a questão política se evidencia: o discurso reto pressupõe a ciência exata das leis de combinação ontológica como ciêncià do Paradigma. Sua posse garante e confirma o paradigma da ciência, coisa que o sofista finge ter e saber. Desta maneira, jogos de linguagem efetuados como discurso reto efetuam um saber do verdadeiro; este, simultaneamente, como é Origem, eleva-se no discurso como doador do sentido dos jogos de linguagem que o constituem, numa circularidade típica do mito. Surge, pois, outra vez a questão que se aflorou antes: se mesmo diégesis é mimética, como é possível falar fora da circunscrição daquilo que se combate, uma vez que o combatido é condição e origem da enunciação? Enfim, como ser anti-mimético na mímesis?

Nos Diálogos, paralelo ao antagonismo explícito quanto a poetas e sofistas, observa-se outro movimento, mais secreto, modulado como estratégia discursiva e que, retoricamente pensado, é já um agir dentro do mimetismo que se combate. Neles, a mímesis e seus discursos proliferantes vão sendo teatralizados como se, ao colocá-los em cena no discurso, fosse possível capturá-los, domesticá-los e imobilizá-los através da teoria - o que, evidentemente, fracassa, pois é impossível definir mímesis, nesse sistema montado pouco a pouco, em termos essenciais.. Em outros termos, sua própria postulação implica a diferença do discurso definidor como um produto mimético . Opera-se, pois, um deslizamento: trata-se dos efeitos da mímesis e, pelo seu acúmulo, espécie de operação de sinédoques que vão tomando a parte pelo todo, avança-se o discurso com o fim de pensar todo o sensível como visibilidade mimética para então, cegando-a com o teórico, remetê-la à invisibilidade absoluta da idéa efetuada sempre como pressuposto ou Origem. O que significa que, nos Diálogos, um poder vai sendo tramado juntamente com um saber, não importam as reiteradas afirmações sobre a ignorância do poder e a pureza do saber, que apenas denegam a operação.É neste sentido, ainda, que a idéa é um produto.Para discuti-lo, o atalho agora é um caminho que não leva a parte alguma na Floresta Negra.

Em Platāo, a idéa é, segundo o filósofo, produto de das dichtende Wesen der Vernunft, da "essência poietizante da razão". Tal essência poietizante (ficcionante e, num sentido particular, que se torna poetizante, "literário", a partir do final do século XVIII, quando se inventa a "literatura"):

...relaciona todo conhecimento humano, isto é, racional, a uma origem superior; 'superior' significa situada essencialmente além da quotidianeidade habitual (...). Aquilo que é percebido pela razão (na razão), 
o ente enquanto ente, não se deixa possuir pelo simples fato de estar à mão. Pensado de maneira platônica,o ente é o presente; a idéia. Quando Platão, por exemplo, no seu Fedro, conta o mito da descida da idéia cá embaixo na alma humana a partir dum lugar supra-celeste, hyperouránios tópos, este mito não passa, pensado de maneira metafísica, da interpretação grega da essência poietizante da razão, isto $e_{\text {é }}$ de sua origem superior (Heidegger, 1968, p.152-158; 1971, I, p. 454) ${ }^{12}$.

Assim, o discurso e a produtividade em geral são mímesis, para Platão, não só como ícone, cópia, simulacro e outros semelhantes da similitude, mas produção, que pressupōe a essência da verdade como alétheia. E, por exemplo, o que escreve na República: mímesis é demiurgia. Também no Sofista, as duas séries iniciais de divisōes com que o Estrangeiro opera, ktetiké e poietiké, juntam-se no final do diálogo, quando a "arte de aquisição" (ktetiké) de coisas naturais é inscrita na "arte de produção" (poietiké), afirmando-se aí que a phýsis é obra da produção divina e, portanto, obra mimetizada pelos homens, que não só imitam quando fazem, mas produzem. Platāo, porém, interpreta a alétheia em termos de retidão e justeza, como orthótes do olhar e da enunciação - e mesmo em termos de homolosis ${ }^{13}$, bastando aqui a exemplaridade da personagem Sócrates para evidenciá-lo.

Embora alétheia enquanto desvelamento é traço fundamental do ente, sofre um deslocamento quando visada pela orthótes do olhar ou do discurso humano, pois ela se dá envolvida no vir-a-ser sensível - o que implica um outro olhar, um outro discurso, "interior" e reminiscente, inteligível. Na ambigüidade, resulta que a verdade é não-velamento e exatidāo, e que o não-velamento se situa sob idéa que, contudo, dá-se no sensível. Desta maneira, se o discurso reto é exatidão interna da enunciação referida à idéa, e se ousia se entende como idéa, a mímesis afeta a participação da coisa na sua idéia - ela processa uma desinstalação e um descentramento ao mesmo tempo que instala e centra a idéia no discurso. Ela des-instala, para jogar aqui com um estilema a-propriado. Logo, como a retidão da enunciação só seria absolutamente rigorosa se estivesse fundada em alétheia, com o descentramento mimético o que se produz na enunciação apenas tem "aspecto $d e^{n}$, dicotomia mantida: veja-se que, na República, os produtos de mímesis são chamados de phainómena, aparências. Assim, mimesis efetua dissimulaçāo: falar é repetir , mas a repetição nāo instala a fala na presença plena. Em outros termos, a produção mimética não instala o eîdos, a presença, como idéa, mas apenas como eldolon - fenômeno, aparência, ídolo, análogo, imagem, figura, simulacro, ícone a tradução é dificílima. Eídolon, além de significar um eîdos apequenado, significa-o de modo pejorativo - é supérfluo, negligenciável no seu modo de se mostrar e aparecer, como uma espécie de "presençazinha" degradada da presença. Escrever eîdos e eldolon, contudo, como faz Platão, indicia que a diferença já está alojada no próprio discurso de alétheia, o que implica a possibilidade de separar-se uma "boa" mimesis de outra "má", certamente "malvada", produtora de eldola.

Poderia ser evidente, aqui, quais sāo seus operadores; contudo, o que também é bastante divertido, é que, indo à caça do estranho animal, o sofista, Platão chega à definição do que se supõe seja o bom animal, o filósofo. Enfim, de lobo a cão; e de cão a lobo, segundo a Canidade. $O$ "divertido" da encenação é que fala "Sócrates", mímema de Sócrates, ficcionando na gráfica do diálogo a constituição da verdade do filósofo e do pseudo-saber do sofista. Sua garantia, supōe-se, é também a suposição de avançar como sinônimo identificado como "próprio", quan- 
do retoricamente é evidente tratar-se de homônimo de homônimo, outro de outro, e epônimo, de empréstimo, fingindo dizer o Mesmo.

Assim, Platão faz exatamente o que combate: ele desapropria-se como autor da enunciação e avança expondo-se mimeticamente dissimulado na fala de outro, "Sócrates", outro de outro, Sócrates. Não há nenhuma contradição, contudo, mas estratégia: certamente paródia da tragédia, talvez mimese de mímesis como construção em abismo, ele sabe que o faz: basta que se observe a freqüência com que $\varepsilon$ referida a arte do marionetista, thaumatopoiikós, quando se trata de mímesis em suas palavras, "jogo gracioso". No mesmo Sofista, contudo, pensa-se o discurso filosófico como anti-mimético. Veja-se como ele o mimetiza.

No Sofista (Platão, 1950, 224 a), pensa-se a injustiça como ausência de qualidades próprias, caracterizando-se a produção mimética do sofista como "artifício", "contrafacção". Assim, quando o sofista $e$ definido como "erístico mercenário", as atividades arroladas sāo polivalentes, unificando-se na interpretaçāo em todas elas, com suas múltiplas tékhnai, o sofista finge tratar da máthesis e efetua mimesis. A coisa é irônica, lembrando-se outra vez que a desapropriação é política.

O termo "política", aqui platonicamente pensado, tem sua significaçāo explicitada quando relacionado com "teórico", pois trata-se, pela teoria, de determinar a máthesis como propriedade do filósofo que exclui da Cidade, pelo seu saberpoder, o pseudo-saber do sofista, também constituído na operação como um pseudo-poder.

Platāo escreve que o filósofo tem o saber da díke, justeza/justiça assegurada pelas leis de combinação ontológica, o que remete o leitor do diálogo à teoria dos gêneros supremos e ao dialético que, segundo ele, enuncia segundo o discurso reto. Desta maneira, a relação de mímesis com o político é uma relação de linguagem - e nem tanto da linguagem enquanto "mentira", "falsidade" ou "ficção", que são efeitos, mas antes relação de linguagem como potência de produtividade de tipos e gêneses cuja ficção possa impor-se como imagem da verdade. Por isso, o mal político é pensado como operação discursiva que opera disjunções: ele $e$ o que se posiciona fora do teórico e que, ao mesmo tempo, desloca-o, numa careta zombeteira e maligna. Assim, também, o sofista é o "animal", lobo, peixe e logo cão, excluído da humanidade platônica, e o "delirante", excluído do lógos reto.

Trata-se, na encenação, de constituir e impor uma tipologia, o que se lê evidente na República, quando o tema é a educação. Aí, depois de escolher a ginástica para o corpo e a música para a alma, ambas articuladoras da máthesis, Platão passa a examinar o discurso (a parte verbal) da música, reconhecendo duas formas nele: um verdadeiro (alethés) e um falso (pseados) (Platão, 1948, $376 \mathrm{e}$, $377 \mathrm{a} / \mathrm{b})$. Como o que se ensina às crianças são fábulas - mýthoi - e, como fábulas, mentiras, ainda que possam conter algo de verdadeiro - lembre-se que diferencia haplè diégesis de mímesis -, a música deve ser ensinada antes que a ginástica, pois a alma da criança é maleável e, como tal, modela-se melhor, sendo mais fácil impor-lhe o tipo. Trata-se de conduzi-la, levando-a a participar desde cedo do alethès lógos, discurso do nomothétes mediado pelo filósofo, cuja enunciação diegética é modelar. Logo, a desmontagem/crítica da ficção das fábulas visa a instalar o discurso de verdade na Verdade; tal instalação opera convicta de que o discurso mentiroso (fictício, falso, principalmente em suas modalidades disjuntivas, como os dissoi lógoi de Protágoras ou os elkona de Górgias) leva seu agente (e paciente) a ser falado pela empiria ou, ainda, em outras palavras, escreve delirantemente 0 
agente, uma vez que o inscreve no mímema (Platão, 1948, $377 \mathrm{c} / \mathrm{d}$ ). E talvez interessante observar-se aqui, de passagem, que, embora haja um elemento de segundo grau na escrita que a faz "bastarda", pois é mímesis de mímesis (supondo-se a anterioridade sonora e poiética da fala, como no mito de Thot relatado no Fedro), as críticas visam antes de tudo o discurso oral, pois este é enunciação de um agente já "escrito", isto $e$, já teatralizado no sensível quando enuncia. Na escrita, também ocorre um distanciamento óbvio entre o enunciado e a enunciação, entre o lógos dito e sua léxis, não sendo possível identificar-se o próprio do agente do texto, que se rebate na anonímia, ao passo que, no discurso oral, o locutor pode coincidir ou não com sua própria enunciação, sendo "(ir)responsável" conforme sua fala seja identificada como mimética ou diegética. Há, também, uma determinação imediatamente pragmática: a decisão pública das causas em Atenas através de discursos orais. Em todos os casos, porém, a questão política é questão retórica: prescrever os modos de falar implica a normatividade da pólis. Nessa estratégia, o sofista é o animal mimético, o que significa que também é o não-animal e ainda outra e outra coisa, indefinidamente. Mas "Sócrates" também, e duplamente, talvez triplamente: sinônimo homônimo de Sócrates, epônimo de Plato, mimetizado na escrita como fala diegética. Nos Dialogos, tal articulação relaciona-se à análise do ser da linguagem.

$\mathrm{Na}$ medida que a produção humana mimetiza a poietiké divina produtora da phýsis (Platão, 1950, 265 b/c, 266 b/c/d), percebe-se a exterioridade da linguagem em relação às coisas e, ao mesmo tempo, sua naturalidade - o que hoje a Lingüística chamaria de seu convencional/imotivado e sua motivaçāo a posteriori, uso. Como o sofista diz, por exemplo, que tudo é verdadeiro ou que nada é comunicável, e também porque a substância sonora da fala é natural, postula-se obliquamente uma designação natural para cada coisa (Platão, 1931, $383 \mathrm{a} / \mathrm{b}$ ) ${ }^{14}$, ainda que isso depois seja ironizado em nome da convenção dos usos (Platão, 1931, 435 a/e) e, como ocorre com a questão do não-ser no Sofista, da diferença. Trata-se, nos Diálogos, de firmar posição quanto às teorias tradicionais da naturalidade e da convenção: trata-se de fundi-las, fundando-se uma iconografia. É o que se faz no Crátilo, em que a discussão da linguagem induz à constituição de uma "semântica" original, base da enunciação reta e do ataque à retórica sofista.

Na primeira parte do diálogo, em que Sócrates, a personagem, prova a justeza da tese de Crátilo - a existência, naturalmente, phýsei, de uma denominação justa para cada coisa, a mesma para todos, contra a de Hermógenes, que só admite a convenção individual - a postulação de uma expressividade ou de uma "semântica" de base fônica, como se lê no trabalho das sofisticadíssimas etimologias, remete os nomes analisados diretamente ao Paradigma. Na operação, o diálogo efetua espécie de circularidade, do significado do nome para o seu som, mas tomando-se a este não como forma, mas como o que hoje se diria "substância da expressão", naturalmente, como ponto de partida. Assim, a origem dos nomes e da linguagem, pesquisada nos significados, sempre se rebate como linguagem da origem através da sonoridade "natural", estabelecendo-se nas etimologias o jogo da presença/ausência em procedimento especular. Na operação, postula-se que o Significado já se encontra inscrito idealmente em seu significante, o que torna possível a decomposição do som - por exemplo, dos nomes Astyánax e Skamándrios - em fonemas que, sendo embora diferentes, recobrem o mesmo significado lingüístico figurado nos sinônimos. A suspensão do arbitrário é aqui, platonicamente, possibilidade de participação de letras e sons diferentes na mesma forma, pois os nomes compostos 
por eles têm um designado que 'é katd phýsin - donde, também, sua orthótes, ou retido. Ao mesmo tempo, a operação etimológica torna necessário explicar-se a relação som/coisa, depois que se analisou a relação som/significado. O processo leva de imediato à desconfiança da linguagem, pois a essência desta é identificada à imitação mimética. Por isso, Platão postula que a imitação não deve ater-se ao som que, embora seja natural, também é da ordem do sensível, nem à forma aparente da coisa, nem à cor etc.: como a idéa é anterioridade sagrada, o nome deve imitar a essência da coisa com suas letras e sílabas (Platão, 1931, 423 e). Deste modo, embora a forma da palavra não possa assemelhar-se à forma empírica da coisa, postula-se uma semelhança de mais alta estirpe: a semelhança que faz do nome uma imitação da coisa em sua verdade. Assim, o ếdos é paradigma do lógos (Platão, 1931, 439 a): a expressividade natural de vogais e consoantes advoga uma motivação original, criada pelo nomothétes, entre nome/som/coisas. Lembre-se outra vez que a phýsis é produto da poietiké divina.

Este é, contudo, apenas um movimento do Crátilo, que apresenta nova dramatização: depois de profusamente discutida e provada, a tese da relação natural nome/coisa sofre refutação, que começa no momento em que Crátilo, satisfeito com as provas excelentíssimas de Sócrates, diz não ser possível haver algum nome mal posto, pois todos são justos - afirmando, portanto, ser impossível o discurso falso (Platão, 1931, 429) ${ }^{15}$, numa fala em que ressoa o dito de Protágoras citado por Sexto Empírico no início deste.

Sócrates demonstrará a Crátilo que o nome é, como a pintura, uma imitação da coisa e que, como mímesis, pode ser inexato.Segundo Crátilo, a dýnamis dos nomes é ensinar e possibilitar a compreensão das coisas - o que Sócrates refuta, dizendo-lhe ser sempre possível o engano na procura das coisas se os nomes são tomados como guias. Seu argumento decisivo é o que converte a tese de Crátilo em petição de princípio(Platão, 1931, 439 b): havendo reconhecido a existência de nomes compostos e derivados, o reconhecimento implica a existência dos nomes primitivos. Em outras palavras, S6́crates introduz a diacronia no sistema- logo, se é com os nomes que se apreendem as coisas, tendo-se como válida a tese de Crátilo, como se explica o descobrimento das coisas quando ainda não haviam sido descobertos os nomes que as designam?

A ambigüidade permanece, contudo: mesmo quando Platão ironiza finamente a necessidade e a motivação da relação som/significaçāo/coisa, voltando-se a ironia contra o mimetismo da linguagem, que duplica o Paradigma nāo sensível, a mera postulação do Paradigma como idéa implica o reconhecimento de tal relação e o espelhismo da mímesis. Daí, também, a implicação necessária da técnica dialética, que exerce uma purificação, ascese da anamnese da idéa como condição da relação justa. Desviando-se da motivação de nome/coisa, de segundo grau, pois o sensível é mimético, indica-se a motivação ideal de nome/eîdos: no limite da operação, misología. O "caso" do sofista é típico: ele é todo efeito, e efeito de discurso.

Assim, a observação mais estranha a ouvidos empiristas e certamente familiar a entendimentos cósmicos é a de que é possível apreender as coisas por elas mesmas sem auxílio dos nomes (Platão, 1931, 438 e): em grego, lógos significa tanto discurso quanto razão. Já se escreveu que, ao que parece, o conhecimento do Bem deveria renunciar inclusive à dialética combinatória e recorrer à intuição, uma vez que é impossível incluir o Ser absoluto numa definição. O conhecimento do Bem é visão extática entre dois discursos ${ }^{16}$. A propósito, a Carta VII, princi- 
palmente 343 b e sgs., enuncia que a visão do Bem custa a vir e só com muita dificuldade é conseguida (Platão, 1952) ${ }^{17}$. No final do Crátilo, pois, Platão parece recusar Heráclito, Protágoras e a doutrina do mobilismo universal; ao mesmo tempo, entra em cena Parmênides: o repouso é condição para que o nome tenha "firmeza". É no Sofista, porém, que Platão se situa a meio caminho entre o Jônio e o Eleata ${ }^{18}$, apropriando-se de Heráclito e "matando" Parmênides pela metade. A discussão do seu procedimento é oportuna, por isso, para se explicitar a questāo retórica.

No Crátilo, e principalmente no Sofista, a linguagem é analisada em dois níveis: o dos "nomes", ou de certo recorte na língua como conjunto de signos (b́noma), e o da frase, como articulaçāo de pensamento e discurso (lógos). Uma das dificuldades é que se diz ónoma e o termo designa "palavra", genericamente, significando principalmente o nome (ónoma) e o verbo (rhêma). Observe-se também que aqui se emprega o termo "signo" com total consciência do seu anacronismo: o conceito de signo implica uma relação de exterioridade ou de substituição diacrítica, ao passo que, platonicamente pensado, o discurso é de participação na forma, não importa o grau de degradação mimética da mesma.

Enquanto ónoma e rhêma têm sentido isoladamente, pois sua significação imita o eîdos, sua enunciaço isolada, como dicção aleatória, não produz o discurso, ainda que siga a ordem diacrônica da fala. E sua combinatória que o efetua, pois, além do sentido, implica a referência a uma situação dada e a predicação, pensada simultaneamente como mistura de ser e de não-ser que participa no eidético ideal. A consideração de nome e discurso é ontológica: os nomes, ainda que se refiram a algo de permanente, parecem incapazes de fixá-lo, uma vez que também são levados no fluxo do vir-a-ser, eles mesmos também sensíveis. Desta maneira, instala-se uma disparidade entre o agente da enunciação e a coisa designada pelo nome se agente e coisa forem tidos como sempre móveis, tornando-se impossível o conhecimento- e a linguagem mesma, pois o discurso "não combina". Advoga-se, portanto, a subsistência de algo em si, para além da aparência sempre móvel. Deste modo, embora a tese de Heráclito seja admitida, sofre a correçāo de Parmênides. Ao mesmo tempo, contudo, a postulação do Ser imóvel leva ao julgamento tautológico, $A=A$. Postular a predicação é dizer, por exemplo, "o homem é bom" e "os homens são bons", o que consiste em introduzir uma determinação de qualidade ou de número no discurso, isto é, em introduzir o outro no mesmo, advogando-se, com isso, a mistura de ser e de nāo-ser.

Para provar-se a diferença, postula-se que o discurso é combinatória cuja fórmula matriz é Nome + Verbo e, nesta, distingue-se, através da dialética, a combinatória falsa da verdadeira: retórica mimética, retórica diegética, retórica sempre mimética. A fórmula $N+V$ implica, portanto, uma teoria do sentido lingüístico, sintático-semântico, e fenomênico. Embora o discurso seja sobre o sensível, pois a função primeira dos elementos lexicais, principalmente ónoma e rhêma, é de nomeação - o que, via Jakobson, hoje seria dito "função referencial"-, é apenas da mistura dos dois paradigmas de signos que se faz o que, com outro anacronismo, é uma morfo-semântica.É que, em sua combinatória, ónoma e rhêma compõem uma semântica fundamental que se postula apofântica, quando diegética, e sofística, quando mimética. Para estabelecer-se o grau da participação reta, a referência do sensível é remetida à idéa - pela sonoridade katà phýsin e imitação da forma ideal - numa sintaxe dialética. $O$ discurso é, assim, simultaneamente natural e convencional devido a mímesis: Forma de forma, eîdos, a idéa se especula degradada na língua, eidolon, forma de Forma. 
Como também é a marca de um acordo entre o homem e as coisas, o discurso tem de demonstrar a relação da coisa quanto a si mesma e, simultaneamente, quanto às outras, uma vez que só tem "firmeza" na medida em que é diferente de todas as outras. Deste modo, contra os que a tudo movem ou contra os que imobilizam a tudo - se é válido pensar que também há alguma firmeza na linguagem - somente quando se demonstra a identidade do idêntico e a alteridade do outro é que ónoma tem tal firmeza. Só então se poderá dizer com certeza da existência do discurso verdadeiro e do falso, uma vez que o falso diz o outro do mesmo, o não-ser do que é, e vice-versa (Platão, 1950, 262 a/e).

Desta maneira, mais uma vez, tem-se de provar a diferença. Sob a aparência didática e analógica da utilização das letras do alfabeto e da consideração dos nomes, articula-se a necessidade, nunca tematizada como tal, de fazer surgir a lei da diferença, a irredutibilidade da estrutura e da relação, da proporcionalidade e da analogia (Derrida, 1972).

Ora, a operação dialética necessariamente implica a ciência do mesmo e do outro. No Sofista (253 c/e), em passagem em que a escrita volta à cena, afirma-se que, assim como há combinação de letras, existe combinação de gêneros; e da mesma maneira que existe uma tékhne da combinatória de letras - a gramática ,também bá uma ciência da combinaçāo dos gêneros - a dialética. Assim, o estabelecimento de uma combinatória gramatical reta é análogo ao de uma combinatória dialética também reta: da junção de discurso/pensamento retos, surge a enunciação do verdadeiro e do falso. $O$ que implica uma retórica normativa, que expele o discurso sofista como jogo e simulacro.

A dialética é a técnica que leva à epistéme: espécie de ciência geral do mesmo e do outro, que deve levar ao conhecimento da symploké onde se engendra o lógos. Como é no discurso que se tem possibilidade de se enunciar o outro sobre o mesmo e como sendo o que não-é (Sofista, $263 \mathrm{a} / \mathrm{c}$ ), é também no discurso que o falso é possível. Como pensamento e discurso são o mesmo (Sofista, 263 e), da junção decorre também a possibilidade da opinião falsa. A questão da falsidade remete circularmente, assim, à questão da mimesis e da retórica sofista. Como se chega a tal resultado é o que se verá a seguir com o Sofista.

$\checkmark$ No início do diálogo ( $218 \mathrm{~d} / \mathrm{e})$ são estabelecidas duas séries que vão sendo divididas e subdivididas pela cadeia do texto; as divisões operam por analogia e a intersecçāo consiste na participação de cada elemento obtido em dois paradigmas, "artes de aquisiçāo", ktetiké, e "artes de produçāo", poietiké, referidos anteriormente neste. Como o sofista e a sofística são escorregadios, pois a um nome ou definição corresponde a polissemia de outros nomes e açōes ecoando em homônimos de homônimos, em falsos sinônimos, em epônimos etc., é necessário haver uma subdivisão dos paradigmas em operaçōes lógicas de exclusão sucessiva de significações, que vai "purificando" o termo obtido, embora sempre se retenha o nome que mais se aproxima da definição do estranho "animal" - peixe, cão, lobo. Desta forma, a disseminação dos significados de "arte de aquisição" pelo texto é, inicialmente, análoga à disseminação das ações do sofista. O discurso visa a cercá-lo em todos os pontos, de tal forma que o diálogo é construidíssima rede de palavras cujas malhas vão lentamente encurralando o "animal". Sem se enunciar explicitamente, o lógos mimético se figura no que perfaz. Há no Sofista, assim, uma operação de analogia proporcional, pela qual a similitude estabelecida entre dois análogos arte de aquisiçāo/arte sofista - efetua equivalência dos dois pela exclusão sucessiva daquilo que, em cada um, é demasiadamente genérico, e pela inclusão das pro- 
porçōes "particulares", que permitem produzir-se uma definição como unidade dos termos análogos. Através da conversa entre o Estrangeiro e Teeteto, em que se exercita a dialética com o esquema "pescador e vara", copia-se a proporção do Paradigma, visto que o lógos verdadeiro, segundo Platāo, vai sendo articulado simultaneamente à técnica dialógica que, neste sentido, é um diagrama totalmente mimético da operaçã̄o analógica, enquanto se finge diegético, entre lobo e cão.

Movem-se os fios das marionetes: entre as várias definiçōes obtidas de "sofista", tem-se que é um contraditor (225 a/e), um anti-lógico; também se lê que seu discurso é erístico e que demonstra aptidão para tudo discutir e para falar sobre tudo. A doxa platônica encena-se, no caso, como conclusão de que um homem não pode saber tudo; logo, o saber sofista é aparente, "opiniático", doxastiké epistéme $(233 \mathrm{c})$. $\mathrm{O}$ aval do verdadeiro assim constituído é a dialética: o sofista é o homem/cão, também lobo/homem e peixe/lobo e outro que, manipulando a aparência, a dóxa da ciência, que é a semelhança (264 b), produz mimemas que visam lucro e persuadem. Desta maneira, pode-se dizer com humor, o sofista não produz apenas parônimos, paródias, paráfrases, paralogismos - também é mestre absoluto na fundação de Paradigmas. Por similitude.

Chegando até aqui, o leitor descobre, talvez, que a questão do não-ser estava implícita já no início do diálogo: Parmênides será parcialmente assassinado, o que também é estranhíssimo, pois permanecerá nem vivo nem morto.

Quando se define o sofista como contraditor ${ }^{19}$, o diálogo rearticula-se num dos paradigmas iniciais, poietiké: o do que sabe e que pode produzir (poieîn) tudo. Como, porém, tal produção participa do não-ser , embora assim não o admita o sofista nem julgue possível dizê-lo ${ }^{20}$, é preciso voltar à dicotomia inicial, aquisição/produção. Num outro paradigma, o que agora se vai dividir é a arte mimética (Sofista, $236 \mathrm{a} / \mathrm{c}$ ). Efetuam-se três outras caracterizaçōes do sofista: é um tagarela, ventríloco, marionete: "o que não sabe que jamais poderia dizer alguma coisa de são" (233 a) ${ }^{21}$; um mágico (235 a); um prodígio (236 d). Desta maneira, para criticar-se a tékhne phantastiké sofista, é imperioso redefinir mimetizar. O que é?

Já se viu anteriormente que mimesis é demiurgia e produção de eidola. Disfarçado no homônimo de um anônimo, o Estrangeiro, Platão define "mimetizar" como técnica suposta, "jogo gracioso" que produz mimemas ou homônimos das coisas que são. A questão nunca colocada é, porém, a de como se pode definir mimesis numa operaçāo mimética e, mais, como se pode definir, se mímesis é o pressuposto de qualquer enunciação - e o diálogo avança.

A homonímia ocupa-se dos nomes - qual é, pois, sua relação com as coisas? A arte mimética, produtora de homônimos, é definida como uma tékhne de pintor, uma gráfica (que remete ạo Crátilo, 424 b; 425 a; 434 a/b; ou a República, X). Na operação, contudo, define-se não a mímesis, mas suas modalidades, através de seus produtos: há uma boa mímesis (retomada no final do diálogo). E a que produz imagens verossímeis, que respeitam as proporçōes do Parádigma, não-mimema. É boa, ainda que suspeita: embora seja eikastiké, também pressupōe a substituição de relaçōes exatas por relaçōes aparentes. A questão, que também não se define, é a de que ponto de vista ela é boa, não importa que se reitere que é visão do Bem etc. Ao seu lado, ou abaixo, para todos os lados, prolifera a má mímesis, como phantastiké: "Eis pois as duas formas que anunciei na arte que fabrica imagens: a arte da cópia; a arte do simulacro" ${ }^{22}$. A tékhne phantastiké é má por afastar-se duplamente: a) do verdadeiro (o Paradigma); b) da verossimilhança (a 
boa cópia) (Platão, 1950, 266 e). Logo, se há uma boa cópia e suas deformações incontroláveis, que dizer daquele frio armazém de formas congeladas da idéa?

Torna-se inevitável o parricídio: refutar Parmênides para lutar contra a proliferação prodigiosa e maligna dos duplos. O semelhante não é, pois não se pode dizer/pensar o nāo-ser, segundo o Eleata. Parmênides ignora a mímesis 23. Torna-se oportuno, assim, estabelecer-se o gênero do ser para se contestar o sofista. E preciso provar que o não-ser tem real existência como não-ser para que haja, então, possibilidade de mimesis e falsidade que poderão ser refutadas. Pelo mesmo caminho, então se chegará à espécie de lógos apropriado, reto, para desvendar a tékhne sophistiké, já que mímesis estará fundada, e desmascarar o prodígio.

O Sofista torna-se, aqui, de grande sofisticação, quando converte o outro no mesmo e captura o discurso sofista nas malhas do seu discurso mimético para constituí-lo como uma de suas espécies degradadas. Para fazê-lo, contudo, há uma aporia a ser superada: o não-ser é impensável; indizível, inefável - dizê-lo é determiná-lo ao lado do $\operatorname{ser}^{24}$. O não-ser é álogon, segundo o Poema. O sofista move-se no falso e nāo o admite porque Parmênides diz que "não se pode dizer o não-ser": como dizia Protágoras, "toda phantasía é verdadeira". Por isso, a operaçāo de distinção/definição dos gêneros supremos é trabalhosamente executada - principalmente a do mesmo e do outro - para poder estabelecer-se distinção entre imagem-fantasma, fantástica, e imagem-ícone, icástica. Tal operação, também deve ser óbvio, refere-se sempre ao discurso e à determinação de uma reta economia política de sua prática. Aqui, pois, o texto platônico sobredetermina a teatralização, mudando-se a forma de tratamento, principalmente quando o Estrangeiro se refere à gigantomakhía espetacular. Teeteto, a personagem, agora se investe de um papel e a cena se encena, dobrando-se, dupla. Numa captatio benevolentiae que Górgias aplaudiria, o Estrangeiro (Platão?) dirige tríplice pedido a Teeteto: ser indulgente; no pensar que comete parricídio, pois o patrikós lógos será como que destituído ${ }^{25}$; não considerá-lo um louco ${ }^{26}$. Regresso dos pressupostos, torna-se necessário analisar as antigas doutrinas sobre o ser. $O$ respeito é irônico: é toda uma raça de titãs que deve ser destruída (Platão, 1950, 243 a : $264 \mathrm{~d}$ ): mimesis do mito, Cronos destruído por Zeus, a profundidade suplantada pela altura. Resumindo - platonize-se ${ }^{27}$ : frente às doutrinas antigas do Um e do Múltiplo, dos Amigos das Formas e, ainda, dos crentes da mobilidade universal, oportuno é "segurar" tudo que é imóvel e tudo que é móvel para dizer o ser que, como se demonstra, não se confunde com o repouso, nẹm com o movimento. Demonstrados os gêneros supremos - o ser, o movimento, o repouso, o mesmo, $o$ outro - e também demonstrada a sua combinação, chega-se à definição de dialética, a técnica que o diálogo exercita desde o início.

Desta maneira, correm duas séries paralelas no texto: a da ontologia, com a combinatória dos gêneros e a decorrência do nāo-ser como tendo real existência como não-ser; a da dialética, que, enformada pela ontologia, opera o discurso reto e é capaz de separar a boa mimesis do simulacro. O que faz através de uma ciência dos nomes cuja orthótes, retido ou justeza, é a referência ao verdadeiro, na medida em que o lógos copia o eîdos, sua forma. Retoma-se, aqui, o termo do iń́cio deste: trata-se de uma mimontologia.

A dialética difere da gramática porque opera com unidades maiores que a palavra (Platāo, 1931, 385 a; 393 d); é a ciência-guia através dos discursos e argumentos (Platão, 1950, 253 a/b). Ela é montada sobre a forma do Paradigma, que é a estrutura da diacrítica, paradigma teórico da divisão, subdivisão, exclusão, 
inclusão que o texto dramatiza desde o início. A diacrítica, por sua vez, é técnica do noas, pois é com o discernimento advindo de seu reto exercício que se atinge a verdade do mesmo: a presença do eîdos. Há uma relação sagrada entre diacrítica / eîdos / purificaçãa ${ }^{28}$ : por isso, a retórica sofista não exerce a purificação, pois desliza seus mimemas no lusco-fusco do não-ser, como um heteróclito que não exerce verdadeiramente a diacrítica. Daí, simultaneamente, a oposição do sofista ao filossofo, que vê o brilho invisível do ser (Platão, 1950, $254 \mathrm{a} / \mathrm{b}$ ).

Qual 6, pois, o ser do sofista? Não é o contrário do filósofo, como comumente é pensado: é sua paródia capturada, se referido ao Paradigma; e incapturável, se referido aos seus efeitos de proliferação deformante da boa forma. Como defini-lo? Entre ícone e simulacro (Platão, 1950, $236 \mathrm{c} / \mathrm{d}$ )? "Animal", o sofista é impossível de se pegar, como o snark, ou o unicórnio, este animal que não existe e é tão lógico.

Por isso, a referência ao ventríloco Euricleu mimetiza-lhe a mimesis: mestre na produção de homônimos de homônimos, em espiral de indeterminação. E, aqui, como o texto platônico é ventríloco, e como gesticula! É que o diálogo se esforça, pragmaticamente, em fixar o lugar do sofista, posicionando-o embaixo, ao lado, aquém, fora, talvez acima, certamente dentro, como extra ou irmão-torto ou bastardo, em relação ao lugar da verdadeira personagem icástica, o filósofo, posicionado por sua vez em relação à atopia da idéa ex-machina.

Além de semanticamente constituir uma tipologia, o diálogo efetua pragmaticamente uma topologia: assim, a (des)constituição do tipo permite que se prove a (im)propriedade do topos, aplicando-se, mais uma vez, uma analogia de proporção, pela qual o filósofo e seu saber expropriam o saber sofista, negando-lhe o direito à fala. O filósofo, a ficção autêntica: com disposição para tudo discutir e falar sobre tudo, prodigiosamente erístico, conservador do Teatro, diretor do espetáculo, ator principal, personagem, autor, roubando toda a cena ao dirigir o olhar do espectador para um ponto cego fora dela, buraco negro supostamente Sol que a ilumina e fundamenta. Platão/Plutāo/psychopompós: o leitor é conduzido, agora, para a região inferior onde o animal lógico, capturado e transformado, é a besta poética - de lobo a cão; e de cão a lobo.

E há mais: como se lê no Sofista, é a mesma mímesis a condição do discurso verdadeiro. Mimesis confunde-se com alétheia. $\mathrm{O}$ que significa que o parricídio, constituinte do falso, não estabelece apenas a impossibilidade de uma presença plena e absoluta do ente ou do ente tomado como Ente dos entes, como mais: o Bem, o Sol que nem mesmo o filósofo consegue olhar de frente, ou a impossibilidade de uma intuição plena da verdade (Derrida, 1972, p. 192 sgs.). Pois mimesis também $\varepsilon$ dissimulação e esquecimento.

Desta maneira, na base da mimontologia platônica, o que efetivamente se estabelece é o princípio diacrítico da symploké, apropriação parcial de Heráclito e morte parcial de Parmênides, como condição para haver discurso, não importando, efetivamente, seja verdadeiro ou falso, pois a semelhança, na operação, também afasta, ao mesmo tempo que aproxima. Para tal, como fica diagramado pela técnica dialógica, o discurso capta os eventos pontuais da enunciação não mais como kairós, mas subordinando-os à identidade pressuposta da idéa, que $\epsilon$ seu modo de cercear toda fuga eventual da significação pelo sensível. Trata-se, sempre, de uma técnica de convergência da forma na Forma, luta contra a indeterminação pensada, talvez, como "loucura", o deinón referido do "nem morto, nem vivo", em que os jogos da bestice proliferam. Não a besteira, obviamente, como "tolice" ou "erro", mas como malignidade do indeterminado, do nonsense ainda no 
falado pelo "Sentido", da paródia sem modelo, dos jogos graciosos com marionetes absolutamente lógicas e das falas ventrílocas sem texto decorado ou gesto previamente aprendido. O sofista é o lobo, estranho animal que ameaça, também peixe e outro, porque sua técnica retórica é a de uma gramática cujas consoantes podem funcionar como vogais, fazendo ligação de tudo com tudo, propondo combinaçōes aleatórias cujo efeito rosna para a repetição, fora das malhas da semelhança doméstica e canina.

Indignada como retórica do bom animal filosófico, a condenação platônica da retórica sofista ainda é só isso: moral, isto é, indignada em nome de um dever-ser que é vir-a-ser da Canidade (Deleuze, 1976). Por isso, a mímesis também é a abertura propícia por onde irrompe toda a zoologia - gêneros, espécies, tipos, caracteres, prescriçōes de trato e adestramento, originais e cópias, raças puras e viralatas, autoridades e plágios. Aristóteles, animal optimum, para variar classificou, categorizou e colocou essa fauna em gaiolas para uso de antigos e nosso, em sua Retórica, e no que sobrou de sua Poética.

A retórica sofista é falsa, assim como seu pensamento, pois enuncia não-seres, sendo uma arte de contraditar que, pela parte irônica de arte fundada apenas na opinião, faz parte da mimética e, pelo gênero que produz simulacros, liga-se à arte de criar simulacros para persuadir. Ela é uma cosmética.Essa porção nãodivina, mas apenas humana da arte de produção que, tendo por domínio próprio os discursos, neles fabrica prestígios e prodígios, eis o que se pode afirmar "que é a raça, que é o sangue" do autêntico sofista - dizendo-se platonicamente, como aparece aqui, a mais pura verdade.

O que é divertido, contudo: a verdade é a presença do ếdos na palavra e na combinatória dialético-gramatical reta, mas o fundamento do visível/dizível já se oculta desde sempre como invisibilidade/indizibilidade absoluta, como um "maisalém-da-presença", epékeina tês ousías. Como escreve Derrida retomando Heidegger e Nietzsche: no discurso assim pensado, todas as presenças sāo suplementos, imagens vicárias, da Origem ausente insistindo circularmente em cada ponto da fala; e todas as diferenças retornam, mais ou menos domadas, no sistema das presenças, como o efeito irredutível do que permanece eternamente Além, Anônimo. De modo que, no discurso oral, a não-verdade é verdade, a não-presença, presença - dualidade que se potencia no discurso escrito. E que a desaparição da presença originária ao mesmo tempo é condição de (im)possibilidade da verdade: o ente aparece, em sua essência, como possibilidade de sua própria duplicaçāo (Derrida, 1972, p. 192 sgs.). Ele só é se houver possibilidade de ser repetido como tal - por exemplo, como opiniāo, no monólogo silencioso da alma consigo mesma; e como imaginação, na mistura de opinião e sensação; e como enunciação, na exteriorização vocal, reta e diegética, de ónoma e rhêma etc.

Fundamenta-se com isso, contudo, somente um verossímil, pois a estrutura de repetição não é dominada pelo valor de verdade, uma vez que a repetição também é empiria, vir-a-ser sensível proliferante loucamente em simulacros. Ação deceptiva, portanto, típica da moralidade dos fundadores de religião. E que $o$ ato de fundar a "justeza" não implica apenas a fundamentaçāo de uma técnica do discurso justo que a estabelece, mas, ironicamente, também sua distorção absolutamente ilimitada e incontrolável, que ecoa em homônimos de homônimos de sinônimos, indefinidamente. Se o estranho animal que é o sofista foi constituído como lobo selvagem para ser capturado e domesticado como cão, a Canidade, ou o que o valha, permitirá, por exemplo, o "bró de jibóia e 
de cavalo" ${ }^{29}$ da indeterminação e todas as variantes perversas da boa mímesis. Por isso, na dualidade, a linguagem é e não é instrumento da verdade que ela mesma postula como seu fundamento, pois nos discursos, tanto retóricos quanto "poéticos", e em suas variadas conexōes, repartiçōes, especializaçōes, o sinônimo da enunciação diegética referida proporcionalmente, como um ortônimo, ao Anônimo do Paradigma, mescla-se, miseravelmente, com o homônimo, que o vampiriza como malignidade incontornável, e o deforma: o que ocorre, aliás, nas melhores famílias.

A plenitude invisibilíssima do Anônimo, aquele que o discurso só aponta reverencialmente, permanece intangível, impossível de ser abarcada numa definiçāo, como um mais-além-da-presença, epékeina tês ousías. E, no entanto, só agora o discurso define, quando se fundamenta um jogo retórico da identidade como chefe dinástico com poder de expurgar os falsos pretendentes, aniquilando-os ou banindo-os, em nome da similitude reta, para fora do círculo agora estranhamente familiar em que a boa semelhança define os laços de parentesco, a descendência reta e legal, e as boas raças. O discurso verossímil, que agora se fundamenta de direito no verdadeiro, opondo-se ao falso pelo direito do fundamento, fundamenta-se efetivamente na força da exclusão. Reflexos do sinônimo reto com que aos poucos vão-se identificando, os discursos verossímeis tornam-se simulacros ótimos da identidade, e são inconfundíveis como critérios ainda agora correntes de decisão política $^{30}$.

\section{Notas}

1- O termo é operado por LACOUE-LABARTHE, Philippe - " Typographie" e por NANCY, Jean- Luc - "Le Ventriloque" in DERRIDA, J.(Apres.)-MIMESIS des Articulations. Paris, Aubier-Flammarion, 1975: $;$

2- Ánoia, no caso, como "ignorância" efetuada pór Platão em oposição à diánoia socrática que mimetiza dialeticamente sua theoría nos Diálogos. Sobre este último termo, cf.Heidegger: "O nome 'teoria' vem do grego theoreîn. O substantivo correspondente é theoría (...) O verbo theoreîn é formado pela união de'dois termos: théa e horáo. Théa (cf. teatro) é o aspecto, a aparência sob a qual alguma coisa se mostra, a vista na qual se oferece. Esse aspecto, sob o qual a coisa presente mostra o que ela é, Platão o chama de eîdos. Ter visto este aspecto, eidénai, é saber. O segundo componente do theoreîn, horáo, significa olhar alguma coisa, captá-la na luz dos olhos, considerá-la. Resulta disso que theoreîn é théan horân: olhar o aspecto sob o qual a coisa presente aparece e, por tal visada, permanecer, vendo, perto dela (...) (Mas) Os Gregos, que duma maneira única pensavam a partir de sua linguagem (...) podiam entender outra coisa no termo theoría (...) Os dois componentes, théa e horáo, podem ser acentuados diferentemente, como theá e óra. Theá é a deusa, como ela aparece a Parmênides, pensador dos primeiros tempos, a Alétheia, a não-ocultação, a partir da qual e na qual a coisa presente deposita sua presença. Traduzimos alétheia pelo termo latino veritas e pelo nosso alemo Wahreit. O grego óra significa a consideração que concedemos. Se pensarmos agora o termo theoria a partir dessas últimas significaçōes, a theoria é agora a atenção respeitosa dada à não-ocultação da coisa presente: A teoria, no sentido antigo (...) é visäo da verdade e guardiā da verdade - das hütende Schauen der 
Wahreit. O termo wara do antigo alto-alemão (donde wahr, verdadeiro, wahren, guardar, e Wahreit, verdade) liga-se à mesma raiz do grego horáo: óra: Fora" (Heidegger, 1958, p.57-59).

Heidegger é, obviamente, referência obrigatória nesses assuntos; contudo, deve-se perguntar o que significa sua operação etimológica. Embora à avessas, pois visa a desinstalar a "metafísica da subjetividade", ela realiza o trabalho de Crátilo: isola morfemas, motivando-os em combinatórias cuja significação se altera pelo deslocamento e fusão; remete o morfológico diretamente ao semântico, sem mediação da prática do discurso; a diacronia à sincronia; línguas a línguas, "vocaçōes a "vocaçōes", como a que faz dos alemães os gregos do século XX... A etimologia, que aparentemente comenta o trabalho de um sujeito na língua e o da língua num sujeito, como uso/estrutura, termina por remeter ao trabalho da língua na língua. Esta consideração é certamente redutora, pois heideggerianamente presa da "metafísica da subjetividade"; não obstante, a operação heideggeriana substitui o vazio metafísico pelo misticismo etimológico. Quanto aos gregos pensarem de modo único a partir de sua língua, imaginem-se as metafísicas dos Platōes ibo, da África Central, cuja língua tem 3 ou 4 verbos "ser", como demonstra Benveniste (Benveniste, 1966, I).

3- Cf. também, sobre a técnica das antilogias e paralogismos de Protágoras, o excelente "Imaginaçāo e Paradoxo", de Jean-François Lyotard (Lyotard, 1979).

4- Em As Nuvens, Aristófanes faz a paródia dos nomes masculinos, femininos e "intermediários" da taxinomia de Protágoras (Aristófanes, 1952).

5- Sobre os dissol lógoi, cf. "Ragionamenti Duplici" (Cardini, 1954).

6- Sobre a equivalência dos modos imitativos platônicos e aristotélicos, cf. "Frontières du récit" (Genette, 1969).

7- Cf. "La pharmacie de Platon" : "Il (y) apparaît en particulier que Platon n'a pas toujours et partout condamné la mimesis. On peut en conclure au moins ceci: qu'il condamne ou non l'imitation, Platon pose la question de la poésie en la determinant comme mimesis(...)". (Derrida, 1972,p. 159). Cf. também Diès: "Platon connaît ce que Condillac appellera le langage d'action. Cf. Cratyle 422 e, 423 e: si nous n'avions ni voix ni langue, nous ferions comme font les sourds-muets, nous essaierions de signifier les choses avec les mains, la tête, et tout le reste de notre corps, et, pour les signifier, mimerions leurs formes, leurs attitudes, leurs mouvements, Platon dit même, leur nature. Mais c'est surtout le langage articulé qui imite l'être des choses" (Platão, 1950, p. 379).

8- Na caçada, Platão opõe as "estátuas animadas", como as de Pigmalião e Dédalo, exemplos de boa mímesis, às "imagens inertes" - como caracteriza, no Fedro, os signos gráficos da escrita, má mímesis porque produtora do esquecimento (Schuhl, 1952, p. 94 sgs.).

9- Segundo Diès, o éthos ou o caráter do discurso teve acepções várias, simultâneas ou sucessivas, de acordo com os retores gregos, que podem ser agrupadas em três chaves: a) o discurso pode analisar o éthos de um personagem em causa: é o éthos psicológico; b) o discurso pode levar os ouvintes a ver o orador de maneira favorável e, assim, pode regular a ação sobre eles, acarretando prestígio para o orador - é o éthos do valor, ou moral; c) o discurso pode "personalizar-se", adquirindo o caráter ou a força da ação sobre o ouvinte - trata-se do éthos dinâmico ou persuasivo. Segundo Diès, a tríplice classificação é típica da retórica de Górgias. Embora a mesma possa ter utilidade como classificação, o psicologismo de Diès a faz anacrônica e exterior às práticas oratórias gregas (Diès, 1927). 
10- Cf.:" Protágoras e Górgias estavam bastante longe dos grandes metafísicos (sic) que os haviam precedido: em um, o heraclitismo tinha levado a um relativismo radical que se aplicava a tudo; o outro virava contra o Eleatismo os argumentos de Parmênides para chegar a um niilismo paradoxal"( Schuhl, 1949, p.323- 324). Cf. também "Gorgia" (Cardini, 1954).

11- Analisando Édipo-Rei, Foucault propōe que, nas sociedades indo-européias do leste mediterâneo, no final do segundo e no início do primeiro milênio a.C., o poder político era sempre detentor de um saber. Tal forma de poder-saber, isolada por Dumézil em seus estudos sobre as três funçōes indo-européias, era a de um poder político mágico e religioso. Segundo Foucault, no século V a.C., a unidade de poder-saber, que existira nos grandes reinos assírios, foi desmantelada; os tiranos gregos, impregnados de civilização oriental, tentariam reabilitá-la em proveito próprio. Cf. "Les fragments religieux" (Ramnoux, 1968, p.385-409). Os sofistas dos séculos V e IV ainda a utilizaram como puderam, na forma de liçōes pagas. A partir de Sófocles, como um ponto de eclosão, segundo Foucault, desaparece a uniāo de poder e saber; a partir dele, o homem do poder será o homem da ignorância. Com Platão, inicia-se o grande mito ocidental da antinomia de saber e poder (Foucault, 1974, p. 39-40). Sobre o tirano, veja-se a personagem Cálicles, do Górgias platônico, apologista do direito da força e da força do direito da força. Seria oportuno relacionar retórica e direito grego, coisa que Platão faz, na apologia incessante da monarquia. A distinção de saber e poder também foi prática, no caso, a despeito dele mesmo: lembre-se sua experiência malograda em Siracusa.

12- Cf. também toda a análise heideggeriana do Mito da Caverna (Heidegger, 1968; 1971, I, p. 454).

13- A mimesis desinstala os lugares estabelecidos de saber/poder na economia das trocas simbólicas; criticando-a como "ignorância", Platão dissocia saber de poder quando desloca da enunciação para o enunciado o critério de validade dos discursos. $O$ poder do tirano, articulado como pseudo-saber da técnica de retores como Górgias ou de filósofos e lógicos como Protágoras, sofistas todos, cai para a dimensão inferior daquilo que nāo participa com proporção no eidético ideal e que, por não respeitar a proporção verossímil da verdade mimetizada nos enunciados retos, nem sequer é "adequado", para falar-se aqui de modo anacrônico, com as categorias do prépon aristotélico posterior. Neste sentido, Sócrates - a personagem - é paradigma do justo, da boa mímesis e da boa verossimilhança.

14- Cf. também o belo livro de Genette, Mimologiques (Voyage en Cratylie), todo ele dedicado à questão da motivação lingüística (Genette, 1976).

15- Seria oportuno rever toda a discussão dos gêneros no Sofista.

16- Cf., especialmente, a nota 83, rodapé da p. 49, em Goldschmidt, 1963.

17- Cf.: "Thùs, at least, I can say about all writers, past or future, who say they know the things to which I devote myself, whether by hearing the teaching of me or of others, or by their own discoveries, that according to my view it is not possible for them to have any real skill in the matter" (Platão, 1952). Any real skill: a desqualificação platônica, feita do ponto de vista da idéa, faz, portanto, que também este texto seja um simulacro.

18- Cf. o que diz Méridier na "Notice" de sua edição do Crátilo: "Le Sophiste fixera la position de Platon entre Héraclite et Parménide: contre le premier, l'auteur du Cratyle établira que le repos ou l'immutabilité est condition nécessaire de l'Intellect, mais en montrant, contre le second, que le mouvement doit être compté comme une des formes nécessaires de l'être. Ainsi, sans nier le mouvement, Platon 
refuse d'en faire l'unique principe de la realite, et d'admettre que tout soit dans un écoulement perpétuel" (Platão, 1931). Cf. também Diès, na "Notice" do Sofista, principalmente "Être, repos et mouvement" (Platão, 1950, p. 286 e sgs.).

19- Evidentemente, Platão constrói um tipo suficientemente genérico para incluir particularidades de vários sofistas.

20- Nas três "definiçōes", o referendo da crítica é a orthótes da boa mimesis, a diégesis: mesmo quando o discurso trata de outra coisa, a retórica continua sendo tematizada.

21- Observar que, no início do diálogo, Sócrates pede ao Estrangeiro que explique a distinção, se há, entre filósofo, sofista e delirante. Excluída a sagrada mania, sofista e delirante produzem efeitos semelhantes, como simulacros.

22- "Cópia" e similares traduzem mímesis, uma vez que o termo também significa produzir/produção e não é definido?

Lembre-se que Platão inclui no simulacro o ponto de vista do observador, em termos do par icásticolfantástico, que posteriormente regulará a cenografia dos tratados de óptica e das anamorfoses (Platão, 1950, 236 b; Deleuze, 1974, p. 263). 23- Leitura apressada veria nisso um erro "lógico" de Parmênides, pois a contradiçāo já se inscreveria no seu lógos: "Não se pode pensar o não-ser..." etc. Conforme Beaufret, a interpretação é anacrônica e platoniza Parmênides, submetendo-lhe o discurso ao critério da contradição, que pressupōe o da verdade platonicamente entendida. (Beaufret,1973).

24- Cf. o texto do poema de Parmênides em Diels-Kranz, 1954, I, p.228-245.

25- Por que é necessário o parricídio para que se estabeleça o discurso sobre o falso? A anonímia é condição do sinônimo e é necessário que um Estrangeiro anônimo (Platão) mate Parmênides para que se produza o discurso do Outro e se introduza o não-ser como homônimo proliferante em torno da unidade do ser, fundando-se o verdadeiro e o falso. No caso, a morte mais uma vez parece ser um procedimento analógico da operação de supressão das antigas doutrinas com que se funda a metafísica.

26- Nesse trecho, o "louco" deve ser um phántasma do filósofo que, por dominar a técnica dialética, tem o discurso constituído retamente, como combinatória proporcionada ao Paradigma. Ao que parece, o delirante é falado por todos os nomes, perdendo-se a diégesis. Na proliferação maligna dos homônimos, produz indeterminação, como uma luz negra que, como má anonímia, perverte o Sol do Anônimo. 27- A partir de uma leitura de Barthes, pode-se sugerir que o resumo implica a preexistência de um "Sentido", ou de "Um", do qual ele é o duplo condensado. A prática do resumo platoniza, pois exorciza o significante como um eidolon cuja exterioridade sensível dissimula o que "realmente" está dito.

28- Cf., no Crátilo, (Platão, 1931, 403 e), passagem em que Sócrates remete o nome Hades a uma definição de "sofista". No trecho, faz-se uma relação entre o nome do deus do mundo invisível, o jogo etimológico de soma/sema (corpo/túmulo/signo) e a mímesis sofística (Platão, 1931, 400 c; 1952, 62 b). Platão se compraz com o trocadilho, jogando com a paronomásia Platāo/Plutāo, metaforizando com o texto o sofista psychopompós, o condutor de almas, que também é.

29- Em Grande Sertão: Veredas, a personagem Hermógenes é caracterizada como ser heteróclito, adýnaton ou quodlibet, em que convergem os homônimos: "bró de jibóia e de cavalo", modo eficaz pelo qual Rosa o constitui também como alegoria do não-ser e como fundo emergente de indeterminação. A ele se opõe Diadorim, alegoricamente mimético como determinação, que figura a relação de idéia, cópia e simulacro no jogo que o texto faz com os sinônimos (Rosa, 1967). 
30- Este texto, que agora se publica com algumas modificaçōes, foi escrito em 1976, como um dos trabalhos do curso de Pós-Graduação em Literatura Grega, "Reflexão sobre a Linguagem do Crátilo", dado pelo Prof. Dr. José Cavalcante de Souza, na FFLCH- USP. Agradeço aqui à minha amiga, a Profa. Dra. Filomena Hirata Garcia, o convite para publicá-lo em Classica.

\section{Referências Bibliográficas}

ARISTÓFANES. Les Acharniens - Les Cavaliers - Les Nuées. Texte établi par Victor Coulon et traduit par Hilaire Van Daele. 5 ed. Paris: Belles Lettres, 1952, t.I.

ARISTÓTELES. Organon I - De l'Interprétation. Trad. et notes par J.Tricot. Paris: Librairie Philosophique Vrin, 1936.

ARISTÓTELES. Organon VI - Les Réfutations Sophistiques. Trad. et notes par J.Tricot. Paris, Librairie Philosophique Vrin, 1939.

ARISTÓTELES. Poetica. Introd., trad., com. di Manara Valgimigli. 3 ed. riveduta. Bari: Laterza \& Figli, 1946.

BEAUFRET, Jean. "O Poema de Parmênides" in "Parmênides de Eléia" in Pré-Socráticos. São Paulo: Abril Cultural, 1973, I.

BENVENISTE, Émile. "Catégories de pensée et catégories de langue" in Problèmes de linguistique générale. Paris: Gallimard, 1966, I.

CARDINI, Maria Tiampanaro. I Sofisti. Bari: Laterza \& Figli, 1954.

DELEUZE, Gilles. "Platão e o Simulacro" in Lógica do Sentido. Trad. de Luís Roberto Salinas Fortes. São Paulo: Perspectiva, 1974, Col. Estudos, 35.

DELEUZE, Gilles. Différence et répétition. 3 ed. Paris: PUF, 1976.

DERRIDA, Jacques. "La pharmacie de Platon" in La dissémination. Paris: Seuil, 1972. DIES, Auguste. "Philosophie et rhétorique" in Autour de Platon - Essais de critique et d'histoire. Paris: Gabriel Beauchesne, 1927.

DIÓGENES LAÉRCIO. 1,IX in "80 A- Protagoras. Leben und Lehre" in DIELSKRANZ. Die Fragmente der Vorsokratiker. Grieschisch und Deutsch von $\mathbf{H}$. Diels. Siebente verbess.Aufl. herausg.von W. Kranz. Berlin: Weidmannsche Verlagsbuchhandlung, 1954, II.

FOUCAULT, Michel. $A$ Verdade e as Formas Juridicas. Rio de Janeiro: Cadernos da PUC, 1974, Série Letras e Artes, 16.

GENETTE, Gérard. "Frontières du récit" in Figures II. Paris,:Seuil, 1969, "Tel Quel".

GENETTE, Gérard. Mimologiques (Voyage en Cratylie). Paris: Seuil, 1976, Col. Poétique.

GOLDSCHMIDT, Victor. A Religião de Platão. São Paulo: DIFEL, 1963.

GORGIAS - "82. A. Leben und Lehre."; "B. Fragmente" in DIELS-KRANZ. Die Fragmente der Vorsokratiker. Griechisch und Deutsch von H. Diels. Siebente aufl. herausg. von W. Kranz. Berlin: Weidmmansche Verlagdbuchghandlung, 1954, II.

HEIDEGGER, Martin. La doctrine de Platon sur la verité (Platonslehre von der Wahreit) in Questions II. Paris: Gallimard, 1968.

HEIDEGGER, Martin. Nietzsche. Paris: Gallimard, 1971, I.

ISÓCRATES. "Contre les sophistes" in ISOCRATE-Discours. Texte établi et traduit par G. Mathieu et E. Brémond. 2 ed. Paris: Belles Lettres, 1956, t.I. 
LACOUE-LABARTHE, Philippe. "Typographie" in DERRIDA, Jacques (Apres.). MIMESIS des Articulations. Paris: Aubier-Flammarion, 1975.

LYOTARD, Jean-François. "Imaginação e Paradoxo" in Discurso. São Paulo: DFFFLCH-USP/Livraria Editora Ciências Humanas, 1979, no. 10.

NANCY, Jean-Luc. "Le Ventriloque" in DERRIDA, Jacques (Apres.). MIMESIS des Articulations. Paris: Aubier-Flammarion, 1975.

PARMÊNIDES. "B. Fragmente" in DIELS-KRANZ. Die Fragmente der Vorsokratiker. Griechisch und Deutsch von H. Diels. Siebente aufl. herausg. von W. Kranz. Berlin: Weidmannsche Verlagsbuchhandlung, 1954, I.

PLATÃo. Cratyle. Texte établi et traduit par Louis Méridier. Paris: Belles Lettres, 1931.

PLATÃo. Phèdre. Texte établi et traduit par Léon Robin. Paris: Belles Lettres, 1944.

PLATÃo. La République. Traduction d'Émile Chambry. Introd. d'Auguste Diès. Paris: Belles Lettres, 1948, Livres I-IV.

PLATÃo. La République. Traduction d'Émile Chambry. Introd. d'Auguste Diès. Paris: Belles Lettres, 1948, Livres V-X.

PLATÃo. Ion-Ménexène- Euthydème. Texte établi et traduit par Louis Méridier. Paris: Belles Lettres, 1949.

PLATÃo. Gorgias - Ménon. Texte établi et traduit par Alfred Croiset.Avec la collaboration de Louis Bodin. Paris: Belles Lettres, 1949.

PLATÃo. Philebe. Texte établi et traduit par Auguste Diès. Paris: Belles Lettres, 1949.

PLATÃO. Le Sophiste. Texte établi et traduit par Auguste Diès. 2 ed. Paris: Belles Lettres, 1950.

PLATÃo. Théétète. Texte établi et traduit par Auguste Diès. Paris: Belles Lettres, 1950.

PLATÃo. Phédon. Texte établi et traduit par Léon Robin. Paris: Belles Lettres, 1952.

PLATÃO. The Seventh Letter. Transl. by J. Harward. Chicago: Cambridge University Press, 1952.

PLATÃO. Protagoras. Texte établi et traduit par Alfred Croiset. Avec la collaboration de Louis Bodin. Paris: Belles Lettres, 1955.

QUINTILIANO. Institution oratoire. Traduction nouvelle d'Henri Bornecque. Paris: Garnier, s/d, Livro IV.

RAMNOUX, Clémence. Héraclite ou L'Homme entre les Choses et les Mots. 2 ed. Paris: Belles Lettres, 1968.

REY, Alain. "Les propositions grecques" in REY, A.. Théories du signe et du sens. Paris: Klincksieck, 1973.

ROSA, João Guimarães. Grande Sertão: Veredas. $5^{\mathrm{a}}$ ed. Rio de Janeiro: José Olympio, 1967.

ROSA, João Guimarães. "Das Efemérides Orais" in "Sobre a Escôva e a Dúvida" in Tutaméia (Terceiras Estórias). Rio de Janeiro: José Olympio, 1967.

SAITA, G.. L'Illuminismo della Sofistica Greca. Milano: Fratelli Bocca Editori, 1938.

SCHUHL, Pierre-Maxime. Essai sur la formation de la pensée grecque. Introduction historique a une étude de la philosophie platonicienne. Paris: PUF, 1949.

SCHUHL, Pierre-Maxime. Platon et l'art de son temps. Paris: PUF, 1952. 
SÊNECA. Ep. Luc. in "80 A. Protagoras. Leben und Lehre." in DIELS-KRANZDie Fragmente der Vorsokratiker. Griechisch und Deutsch von H. Diels. Siebende verbess.Aufl. herausg. von W. Kranz. Berlin: Weidmannsche Verlagsbuchhandlung, 1954, II.

SEXTO EMPIRICO.Adv. Math. in "80 A. Protagoras. Leben und Lehre." in DIELSKRANZ- Die Fragmente der Vorsokratiker. Griechisch und Deutsch von $\mathrm{H}$. Diels. Siebende verbess. Aufl. herausg.von W.Kranz.Berlin:Weidmannsche Verlagsbuchhandlung, 1954, II.

HANSEN, J. A.. Orthonym, Synonym, Homonym: Rhetoric of the Anonym. Classica. São Paulo, 5/6: 33-56, $1992 / 1993$.

ABSTRACT-In Plato's Dialogues, rhetorical questions are included as mimontology or a dramatization of ideal types and genesis. Cratylus' discussion about langage and Sophist's analysis of dialectics formulate the diagram of an original "semantics" and its "orthotical" syntaxis that are stated by Plato as a non-mimetic basis of mimesis as alétheia against sophistic practices of discourse. KEY WORDS: Mímesis, diégesis, dialectics, ônoma, rhêma, ontology, eldos, sophist, verisimilitude. 